\title{
Front Matter: Volume 9479
}

, "Front Matter: Volume 9479," Proc. SPIE 9479, Open Architecture/Open Business Model Net-Centric Systems and Defense Transformation 2015, 947901 (28 May 2015); doi: 10.1117/12.2197669

SPIE. Event: SPIE Defense + Security, 2015, Baltimore, MD, United States 


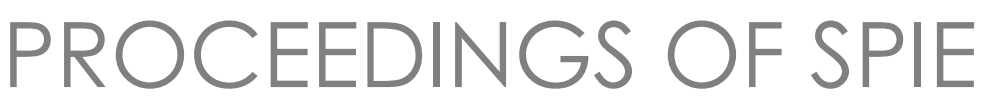

\section{Open Architecture/Open \\ Business Model Net-Centric Systems and Defense Transformation 2015}

Raja Suresh

Editor

21-23 April 2015

Baltimore, Maryland, United States

Sponsored and Published by

SPIE

Volume 9479 
The papers included in this volume were part of the technical conference cited on the cover and title page. Papers were selected and subject to review by the editors and conference program committee. Some conference presentations may not be available for publication. The papers published in these proceedings reflect the work and thoughts of the authors and are published herein as submitted. The publisher is not responsible for the validity of the information or for any outcomes resulting from reliance thereon.

Please use the following format to cite material from this book:

Author(s), "Title of Paper," in Open Architecture/Open Business Model Net-Centric Systems and Defense Transformation 2015, edited by Raja Suresh, Proceedings of SPIE Vol. 9479 (SPIE, Bellingham, WA, 2015) Article CID Number.

ISSN: 0277-786X

ISBN: 9781628415957

\section{Published by}

\section{SPIE}

P.O. Box 10, Bellingham, Washington 98227-0010 USA

Telephone +1 3606763290 (Pacific Time) · Fax +1 3606471445

SPIE.org

Copyright @ 2015, Society of Photo-Optical Instrumentation Engineers.

Copying of material in this book for internal or personal use, or for the internal or personal use of specific clients, beyond the fair use provisions granted by the U.S. Copyright Law is authorized by SPIE subject to payment of copying fees. The Transactional Reporting Service base fee for this volume is $\$ 18.00$ per article (or portion thereof), which should be paid directly to the Copyright Clearance Center (CCC), 222 Rosewood Drive, Danvers, MA 01923. Payment may also be made electronically through CCC Online at copyright.com. Other copying for republication, resale, advertising or promotion, or any form of systematic or multiple reproduction of any material in this book is prohibited except with permission in writing from the publisher. The CCC fee code is 0277-786X/15/\$18.00.

Printed in the United States of America.

Publication of record for individual papers is online in the SPIE Digital Library.

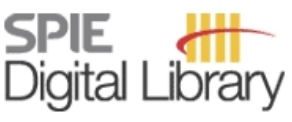

SPIEDigitallibrary.org

Paper Numbering: Proceedings of SPIE follow an e-First publication model, with papers published first online and then in print. Papers are published as they are submitted and meet publication criteria. A unique citation identifier (CID) number is assigned to each article at the time of the first publication. Utilization of CIDs allows articles to be fully citable as soon as they are published online, and connects the same identifier to all online, print, and electronic versions of the publication. SPIE uses a six-digit CID article numbering system in which:

- The first four digits correspond to the SPIE volume number.

- The last two digits indicate publication order within the volume using a Base 36 numbering

system employing both numerals and letters. These two-number sets start with 00, 01, 02, 03, 04, $05,06,07,08,09,0 A, 0 B \ldots 0 Z$, followed by 10-1Z, 20-2Z, etc.

The CID Number appears on each page of the manuscript. The complete citation is used on the first page, and an abbreviated version on subsequent pages. Numbers in the index correspond to the last two digits of the six-digit CID number. 


\title{
Contents
}

\author{
$\checkmark \quad$ Authors \\ vii Conference Committee
}

\section{AFFORDABILITY CONSIDERATIONS IN MILITARY SYSTEMS}

947904 A reconfigurable electromagnetic interface to ease requirements on phased array common modules [9479-3]

947905 Optically controlled GeTe phase change switch and its applications in reconfigurable antenna arrays [9479-4]

947906 Impact: a low cost, reconfigurable, digital beamforming common module building block for next generation phased arrays [9479-5]

947908 Vanadium dioxide phase change switches [9479-7]

\section{OPEN ARCHITECTURE SYSTEMS}

9479 0A A systems approach to achieving the benefits of open and modular systems [9479-9]

9479 OC Open architecture design and approach for the Integrated Sensor Architecture (ISA) [9479-11]

9479 OE Modular open RF architecture: extending VICTORY to RF systems [9479-13]

9479 OL Development of a video SAR for FMV through clouds (Invited Paper) [9479-20] 
Proc. of SPIE Vol. $9479947901-4$

Downloaded From: https://www.spiedigitallibrary.org/conference-proceedings-of-spie on 26 Apr 2023 Terms of Use: https://www.spiedigitallibrary.org/terms-of-use 


\section{Authors}

Numbers in the index correspond to the last two digits of the six-digit citation identifier (CID) article numbering system used in Proceedings of SPIE. The first four digits reflect the volume number. Base 36 numbering is employed for the last two digits and indicates the order of articles within the volume. Numbers start with 00, 01, 02, 03, 04, 05, 06, 07, 08, 09, 0A, 0B...0Z, followed by 10-1Z, 20-2Z, etc.

Altvater, Gregor, 05

Chau, Loc, 05

Chen, Bill, 06

Dirner, Jason, OE

El-Hinnawy, Nabil, 05

Field, M., 08

Fulton, Caleb, 06

Ghalichechian, Nima, 05

Griffith, Z., 08

Guo, Alex, 06

Hacker, J., 08

Harrell, John, OC

Hepp, Jared J., OC

Hillman, C., 08

Ho, James G., 05

Hoffmann, Ted, 06

Johnson, Michael, $\mathrm{OE}$

Kogut, Michael, OC

Krzywicki, Alan T., OC

Lan, Xing, 05

Lee, K.-J., 08

Lee, R. T., 04

Melber, Adam, OE

Morris, A. P., 04

Moulton, Christine L., OC

Murmann, Boris, 06

Nichols, Doyle, 05

Paulsen, Lee, 06

Pearson, Gavin, OA

Saunders, Austin, 06

Smith, Richard, OA

Stupar, P., 08

Thompson, Dan, 06

Tripp, Howard, OA

Volakis, John, 05

Wallace, H. Bruce, OL

Westafer, R. S., 04

Worthington, Olwen, OA

Yeary, Mark, 06

Young, Robert M., 05 
Proc. of SPIE Vol. $9479947901-6$

Downloaded From: https://www.spiedigitallibrary.org/conference-proceedings-of-spie on 26 Apr 2023 Terms of Use: https://www.spiedigitallibrary.org/terms-of-use 


\section{Conference Committee}

Symposium Chair

Nils R. Sandell Jr., Strategic Technology Office, DARPA

(United States)

Symposium Co-chair

David A. Logan, BAE Systems (United States)

Conference Chair

Raja Suresh, General Dynamics Advanced Information Systems (United States)

Conference Program Committee

Robert Bond, MIT Lincoln Laboratory (United States)

Vasu D. Chakravarthy, Air Force Research Laboratory (United States)

Megan Cramer, U.S. Navy PEO LCS (United States)

John S. Eicke, U.S. Army Research Laboratory (United States)

Thomas Green, SAIC (United States)

Nickolas Guertin, U.S. Navy (United States)

Michael A. Kolodny, U.S. Army Research Laboratory (United States)

Leo J. Rose, U.S. Air Force (United States)

Jason R. Stack, Office of Naval Research (United States)

Session Chairs

Affordability Considerations in Military Systems

Roy H. Olsson III, DARPA (United States)

Open Architecture Systems

Jason R. Stack, Office of Naval Research (United States)

Megan A. Cramer, U.S. Navy (United States)

Self-organizing Collaborative Unmanned ISR Teams I: Joint session with Conferences 9479 and 9468

Raja Suresh, General Dynamics Advanced Information Systems (United States)

Robert E. Karlsen, U.S. Army Tank Automotive Research, Development and Engineering Center (United States) 
Self-organizing, Collaborative Unmanned ISR Teams II: Joint session with conferences 9479 and 9468

Raja Suresh, General Dynamics Advanced Information Systems (United States)

Robert E. Karlsen, U.S. Army Tank Automotive Research, Development and Engineering Center (United States)

MAST: Bio-inspired Control: Joint Session with Conferences 9467, 9468, 9479

Christopher M. Kroninger, U.S. Army Research Laboratory (United States)

William D. Nothwang, U.S. Army Research Laboratory (United States)

MAST: Scale Legged Locomotion: Joint Session with Conferences

9467, 9468, 9479

Christopher M. Kroninger, U.S. Army Research Laboratory (United States)

William D. Nothwang, U.S. Army Research Laboratory (United States)

ISR Systems

Raja Suresh, General Dynamics Advanced Information Systems (United States) 